\title{
PENERAPAN PROJECT BASED LEARNING UNTUK MENGEMBANGKAN LIFE SKILL DAN MENINGKATKAN HASIL BELAJAR SISWA KELAS XII IPA-4 MAN TUBAN TP 2016/2017 PADA KONSEP POLIMER
}

\author{
Shorihatul Inayah a \\ aMAN Tuban
}

\begin{abstract}
Abstrak - Kimia Polimer membosankan bagi siswasehingga perlu dibantu pengaplikasiannya. Perlu adanya pengembangan life skillmenghasilkan produk. Siswa dapat membuat produk slime karena banyak diminati. Keuntungan Model ini siswa memanfaatkan konsep Polimer melalui Project Based Learning. Indikator keberhasilan yaitu nilai tes formatif, laporan proyek $>80$ serta kualitas produk. Penelitian dilaksanan 2 siklus, persiklus terdiri dari4 tahapan. Siklus 2 indikator keberhasilan tercapaidari nilai kinerja menyelesaikan proyek. Project Based Learning dapat meningkatkan hasil belajar siswa Kelas XII IPA-4 MAN Tuban TP 2016/2017 dari nilai formatif 30 siswa (83\%), laporan proyek 32 siswa (88\%) dan 34 siswa (94\%) menghasilkan produk berkualitas.
\end{abstract}

Kata kunci: project based learning, life skill, polimer, Slime

\begin{abstract}
Polymer is boring for students so is needs to be assisted in its application. Need for ive skill development to produce product. Student can make slime products because of great interest. Advantages that model student take advantage of Polymer concept through Project Based Learning.Indicator of success are formative test score, project report $>80$ and product quaity. Research carried out 2 cycle, the cycle consists of 4 stages. Cycle 2 Indicatoris achieved from the performance value of completing the project. Project BasedLearning can improve students learning outcomes of class XII IPA-4 MAN Tuban TP 2016/ 2017 from formative value of 30students (83\%), project report 32students $(88 \%)$ and 34students $(94 \%)$ produce quality product.
\end{abstract}

Keywords: project based learning, life skill, polymer, Slime

\section{PENDAHULUAN}

Implementasi Kurikulum 2013 menuntut guru untuk menyusun pola pembelajaran yang berpusat pada siswa (student centered learning), (Thonthowi, 2016). Dalam proses mengajar peranan guru bukan semata-mata memberikan informasi, melainkan juga sebagai pengarah dan memberikan fasilitas (direct and fasilitated the learning). Agar belajar mengajar lebih memadai, maka diupayakan dengan menentukan strategi yang tepat, media yang optimal, perencanaan yang matang dan sebagainya. 
Guru inspiratif bukan mengejar kurikulum, tetapi mengajak berfikir kreatif (maximum thimbking), (Carrin dan Sund, 2009). Guru inspiratif mampu melahirkan pembaharu yang berani menghancurkan kebiasaan lama yang tidak baik. Kreatifitas dapat dipandang dari segi kepribadian, proses, produk dan pendorong. Tindakan kreatif muncul dari keunikan pribadi dalam interaksi dengan lingkungannya. Stember dalam Munandar (2009) menyatakan bahwa kreatifitas merupakan titik pertemuan yang khas antara atribut intelegensi, gaya kognitif, kepribadian dan motivasi. Dari segi proses, proses kreatif mempunyai langkah-langkah metode ilmiah.

Tanggapan siswa selama pembelajaran Kimia pada materi Polimer selama ini adalah metode pembelajaran yang digunakan oleh guru masih berupa ceramah dan hal demikian sangat membosankan bagi siswa. Apalagi materi Polimer merupakan materi yang kurang disenangi dan dipandang sulit karena bersifat teoritis, sehingga perlu dibantu pengaplikasiannya. Oleh karena itu perlu adanya pembelajaran yang menarik serta memupuk daya kreasi dan inovasi siswa supaya tidak monoton dengan adanya program life skill yang menghasilkan produk.

Project Based Learning menjadikan pembelajaran kimia lebih menarik, menyenangkan dan lebih bermakna. Salah satu pengembangan antara lain dalam bentuk life-skill (kecakapan hidup) artinya kecakapan yang selalu diperlukan oleh siswa dimanapun ia berada ketika mengarungi kehidupan, (Djamarah, 2013). Siswa dapat mempelajari proses pembuatan suatu bahan menjadi produk yang bermanfaat, bernilai ekonomi, dan memotivasi untuk berwirausaha. Model pembelajaran ini tidak hanya berorientasi pada bidang akademik, dan vokational semata, tetapi juga mempraktekannya untuk memecahkan problem kehidupan sehari hari, (Arikunto, 2013).

Life Skill (Kecakapan hidup) adalah kecakapan yang dimiliki seseorang untuk mau dan berani menghadapi problema hidup dan kehidupan secara wajar tanpa merasa tertekan, kemudian secara proaktif dan kreatif mencari serta menemukan solusi sehingga mampu mengatasinya. Secara Umum ada dua macam Life Skill, yaitu General Life Skill (GLS) dan Specific Life Skill (SLS). (Tim Broad Based Education 2011). Dalam life skill diharapkan mampu mengembangkan potensi siswa untuk pencapaian suatu kompetensi. ( De Porter, 2009).

Slime sedang marak diminati oleh banyak orang, mulai dari anak-anak hingga dewasa. Karena banyak orang yang menyukai slime, siswa dapat memanfaatkan moment emas ini untuk membuat produk slime. Bermain slime secara tidak langsung juga bisa mengasah otak, khususnya respon fokus, penyalur emosi. Potensi ini dapat dijadikan peluang wirausaha bagi siswa. Slime adalah mainan unik yang terbuat dari percampuran lem (PVC dan PVA) dengan cairan zat yang sama yang terdapat pada detergent. Menurut Eugene (2004:5), secara ilmiah Slime dikatagorikan dalam cairan non-newtion. cairan non-newtion adalah cairan yang tidak mengikuti Hukum Newton.

Tujuan yang ingin dicapai dalam penelitian ini yaitu untuk mengembangkan Life Skill dan meningkatkan hasil belajar Siswa Kelas XII IPA-4 MAN Tuban TP 2016/2017 Pada Konsep Polimer dalam bentuk Slime melalui Project Based Learning. 


\section{METODE}

Penelitian ini dilaksanakan di MAN Tuban Jawa Timur Jl. HOS Cokroaminoto 04 Tuban 0356-321701 pada semester ganjil TP 2016/ 2017 pada bulan Januari-Februari 2017. Subjek yang dalam penelitian ini adalah siswa kelas XII IPA-4 MAN Tuban TP 2016/ 2017 ( $\mathrm{L}=10, \mathrm{P}=26$ ) yang sedang belajar bidang studi Kimia dan guru bidang studi Kimia. Metode dalam penelitian ini adalah deskriptif kualitatif, secara skematis berikut rancangan Tindakan dengan model spiral dari Kemmis dan MC Taggart:

Pelaksanaan tindakan terbagi 2 siklus. Siklus pertama pelaksanaaan pembelajaran menggunakan Project Based Learning dengan materi polimer alam (4 kali tatap muka). Hasil pengamatan dianalisis dan didiskusikan sebagai bahan refleksi untuk rencana tindakan dalam siklus 2. Siklus keduaproses pembelajaran tetap menggunakan Project Based Learning materiPolimer sintetis ( 4 kali tatap muka). Hasil pengamatan dianalisis dan didiskusikan bersama sebagai bahan refleksi untuk melaksanakan penelitian kembali.

Observasi dan Evaluasi dilakukan bersamaan dengan pelaksanaan pembelajaran yang di bantu 4 observer, yaitu guru Kimia di MAN Tuban tentang data: 1) aktivitas siswa dan guru dalam melaksanakan pembelajaran Project Based Learning; 2) kemampuan siswa untuk Mengembangkan Life Skill dengan menghasilkan produk, 3) hasil belajar siswa dalam menjawab soal-soal konsep kimia unsur melalui tes pada akhir siklus.

Data yang telah terkumpul dalam tiap siklus dianalisis dan di diskusikan bersama observer untuk menggali kelemahan dan kelebihan dalam proses pembelajaran. Pada siklus 1 di analisis dan didiskusikan bersama observer, kemudian didiskripsikan sebagai penyusunan tindakan pada siklus 2. Data yang terkumpul pada siklus 2 dianalisis. Hasil analisis data didiskusikan dengan sebagai hasil dan bahan pertimbangan penelitian.

\section{PEMBAHASAN}

Pengembangan Life Skill yang digunakan dalam penelitian ini melalui Project Based Learning. Pendekatan ini, di gunakan dalam hal-hal sebagai berikut: (1) Perangkat pembelajaran, (2) Siswa mengembangkan life skill dalam bentuk kegiatan melakukan riset sederhana secara kelompok sehingga penghasilkan suatu produk, Pembuatan Laporan Proyek, presentasi hasil, mengerjakan test akhir siklus, masing-masing siklus 10 butir soal yang berkaitan dengan kehidupan sehari-hari dari 25 soal yang ditestkan.

Pembelajaran berbasis proyek ini menuntut siswa untuk mengembangkan keterampilan seperti kolaborasi dan refleksi. Dengan pembelajaran berbasis proyek ini siswa terbantu untuk meningkatkan keterampilan sosial mereka, menyebabkan absensi berkurang dan lebih sedikit masalah disiplin di kelas. Siswa juga menjadi lebih percaya diri berbicara dalam kelompok maupun antar kelompok tentang produk yang dihasilkan. Pembelajaran ini tidak hanya cukup diberikan dalam bentuk keterampilan untuk diri sendiri, tetapi keterampilan untuk hidup bermasyarakat, berbangsa dan bernegara.

Kecakapan hidup atau Life Skill dapat dirinci sebagai berikut: (1) kecakapan mengenal diri meliputi kesadaran sebagai mahluk Tuhan, kesadaran akan eksistensi diri dan kesadaran akan potensi diri; (2) kecakapan berfikir meliputi kecakapan menggali informasi, mengolah informasi, mengambil keputusan, dan kecakapan memecahkan 
masalah; (3) kecakapan sosial meliputi kecakapan komunikasi lisan, komunikasi tertulis, dan kecakapan kerjasama; (4) kecakapan akademik meliputi kecakapan mengidentifikasi variabel, menghubungkan variabel, merumuskan hipotesis, dan kecakapan melaksanakan penelitian; (5) kecakapan vokasional sering juga sebagai kecakapan kejuruan. Dalam memilih pengalaman belajar perlu dipertimbangkan kecakapan hidup apa yang akan dikembangkan pada setiap kompetensi dasar. Untuk itu diperlukan analisis kecakapan hidup setiap kompetensi dasar (Djamarah, 2013).

Produk life skill yang dihasilkan diantaranya adalah lilin aromatheraphy dan slime. Slime adalah mainan unik yang terbuat dari percampuran lem (PVC dan PVA) dengan cairan zat yang sama yang terdapat pada detergent. Secara ilmiah Slime dikatagorikan dalam cairan non-newtion. cairan non-newtion adalah cairan yang tidak mengikuti Hukum Newton. Menurut Eugene (2004:5) dalam Hukum Newton dinyatakan bahwa tingkat kekentalan cairan itu konstan dan tidak berubah, seperti air akan terus encer dan mengikuti wadah dan menyesuaikan bentuk tak tergantung berapa tekanan yang diciptakan pada air tersebut. Perbedaan Slime, cairan ini tidak seperti air, tingkat kekentalannya akan berbeda tergantung tekanan yang diberikan pada cairan itu.

Tema-tema yang diterapkan dalam Life Skill harus betul-betul bermakna bagi siswa, baik untuk saat ini maupun untuk kehidupan dikelak kemudian hari. Life Skill diberikan secara tematis mengenai masalah-masalah kehidupan nyata sehari-hari. Pemecahan masalah dalam kehidupan sehari-hari akan membuat para siswa menjadi terlatih untuk menghadapi kehidupan yang nyata. Dengan kecakapan berfikir rasional ini diharapkan siswa tidak akan gamang menghadapi problematika hidup dan kehidupan secara wajar tanpa merasa tertekan.

Antusiasme untuk belajar juga meningkat, ketika siswa bersemangat dan antusias tentang apa yang mereka pelajari, mereka sering mendapatkan lebih banyak terlibat dalam subjek dan kemudian memperluas minat mereka untuk mata pelajaran. Kesadaran akan eksistensi dirinya merupakan kesadaran atas keberadaan diri. Dengan kesadaran atas kemampuan diri itu siswa akan tahu kelebihan dan kekurangannya, kekuatan dan kelemahannya. Antusiasme peserta didik juga cenderung untuk mempertahankan apa yang mereka pelajari, bukan melupakan secepat mereka lulus tes. Maksudnya bahan belajar yang dipilih hendaknya mampu memberikan suatu pekerjaan alternatif bagi siswa.

Tahap persiapan, dilakukan penyusunan perangkat pembelajaran Project Based Learning yang meliputi RPP, LKS, Alat evaluasi (soal-soal yang berkaitan dengan penerapan konsep kimia dalam kehidupan sehari-hari). Dalam persiapan juga dilakukan pembuatan instrumen penelitian yang meliputi: aktivitas siswa dalam proses pembelajaran, lembar penilaian tentang kemampuan siswa menerapkan konsep polimer sehingga didapatkan suatu produk, lembar penilaian sikap siswa, Angket Siswa.

Penelitian di lakukan di kelas XI IPA 4 MAN Tuban TP 2016/ 2017. Jumlah 36 orang, di bagi kedalam 6 kelompok, masing-masing beranggotakan (6 orang). Kelompok diberi nama yang disesuaikan dengan istilah-istilah dalam polimer, misalnya: Monomer, Adisi, Kondensasi, Inisiasi, Propagasi, Terminasi.

Pokok bahasan yang menjadi materi pembelajaran pada siklus 1: Polimer Alam, siklus 2: Polimer sintetik. Untuk setiap siklus 4 kali pertemuan dengan rincian sebagai berikut; pertemuan pertama (1) guru bersama siswa menentukan tema/ topik proyek, 
(2) guru menfasilitasi siswa untuk merancang langkah-langkah kegiatan penyelesaiian proyek beserta pengelolaannya. Pertemuan ke dua (3) guru memberikan pendampingan kepada siswa melakukan penjadwalan semua kegiatan yang telah dirancangnya. Pertemuan ketiga,(4) guru menfasilitasi memonitor siswa dalam melaksanakan rancangan proyek yang telah dibuat. Pertemuan keempat, (5) secara berkelompok siswa mempresentasikan dan mempublikasikan hasil produk, untuk selanjutnya diadakan (6) refleksi terhadap aktivitas dan hasil tugas proyek. Sedangkan pada selanjutnya dilakukan tes akhir siklus, bentuk soal pilihan ganda 20 butir ( 5 option) dengan 10 soal penerapan konsep Kimia polimer dalam kehidupan sehari-hari dan 5 butir soal uraian, dengan 2 soal penerapan konsep Kimia dalam kehidupan sehari-hari. Perbedaan pada tiap siklus terletak pada materi polimer alam dan polimer sintetis.

Pengembangan life skillpada Siklus 1 siswa siswa kurang kreatif untuk membuat produk life skill. Siswa belum mampu melakukan komunikasi lisan, tertulis dan bekerjasama. Tugas life skill monoton dari satu jenis yaitu pembuatan polimer alam lilin aromateraphy. Pada kondisi ini siswa masih terbatasi hanya menerima tugas proyek sesuai petunjuk guru untuk menghasilkan produk. Berdasarkan hasil evaluasi tersebut, maka pada siklus selanjutnya akan dilakukan perbaikan tindakan (improvement) berupa proyek pembuatan produk dari berbagai jenis bahan baku polimer sintetis.

Pada Siklus 2 siswa lebih kreatif dibandingkan pada siklus 1. Siswa sudah mampu melakukan komunikasi secara lisan, tertulis dan sudah mampu bekerjasama, dan juga sudah terampil untuk membuat produk life skill dan memasarkannya. Produk proyek yang dihasilkan dari polimer sintetis adalah slime. Saat membuat slime bisa mencampurkan bahan seperti sabun, deterjen cair, lem povinal, lem fox, lem UHU atau dengan tepung. Shampo merupakan salah satu bahan yang digunakan sebagai pengganti borak dalam slime. Pembuatan berbagai jenis produk sesuai dengan ide dan kreatifitas masing-masing siswa dengan tujuan meningkatkan minat dan kewirausahaan. Siswa masih perlu diingatkan untuk mengemas produk yang menarik dan rapi. Pada siklus ini dapat diketahui efektifitas penerapan project base learning yang dapat mengembangkan life skill siswa. Dasar Pemikiran project base learning sesuai dengan pandangan kontruktivis yang menyatakan bahwa setiap individu secara aktif membangun pengetahuannya sendiri ketika berinteraksi dengan lingkungannya.

Angket diberikan kepada siswa di akhir siklus 2. Siswa di berikan angket balikan dengan tujuan mengetahui minat siswa terhadap pembelajaran yang telah mereka lakukan, serta pengetahuan yang telah diperoleh dari strategi pembelajaran yang telah dilakukan dikelas. Berdasarkan angket sikap siswa, Project Based Learning bagi siswa sangat bermanfaat, sehingga berdampak positif dalam aktivitas siswa pada proses pembelajaran.

Hasil angket balikan menunjukkan 32 siswa (88\%) merasa tertarik dengan pembelajaran Kimia yang dilakukan dengan proyek menghasiilkan produk untuk menyelesaikan persoalan dalam kehidupan sehari-hari serta siswa merasa tidak terbebani dengan proses pembelajaran. Berdasarkan kemanfaatan 36 siswa (100\%) merasa pembelajaran Kimia lebih bermanfaat dengan melakukan proyek, 34 siswa ( 94\%) menyatakan ikut aktif melakukan proyek, 32 siswa (88\%) merasa antusias bertanya kepada guru dalam tahap persiapan, pelaksanaan sampai pelaporan. 
Sedangkan siswa yang akan berusaha selalu menerapkan konsep Kimia dari pembelajaran yang telah dilakukan dalam kehidupan sehari-hari 32 siswa (88\%).

Hasil pembahasan peningkatan hasil belajar siswa tahapan penelitian untuk secara rinci berupa Nilai Tes Formatif, Nilai Laporan Proyek, Nilai Produk. Nilai Tes Formatif Siklus 1 siswa mendapat nilai >80 berjumlah 24 siswa (66\%), sehingga indikator belum tercapai. Untuk itu pada siklus 2 strategi pembagian persoalan, siswa diberi kebebasan untuk menentukan sendiri secara kelompok jumlah siswa mendapat nilai $>80$ berjumlah 30 siswa $(83 \%)$. Banyak sekali manfaat yang dapat diraih melalui penerapan Project Base Learning ini, misalnya: (1) siswa menjadi pembelajar aktif; (2) pembelajaran lebih interaktif atau multiarah; (3) pembelajaran menjadi student centred; (4) guru berperan sebagai fasilitator; (5) mengembangkan kemampuan berfikir tingkat tinggi siswa; (6) memberikan kesempatan siswa memanajemen sendiri kegiatan dan aktivitas penyelesaian tugas sehingga melatih mereka menjadi mandiri; (7) dapat memberikan pemahaman konsep atau pengetahuan secara lebih mendalam kepada siswa.

Nilai Laporan Proyek Pada siklus 1 siswa yang mendapat nilai $>80$ sebanyak 23 siswa (64\%). Setelah dilakukan evaluasi terkait dengan laporan proyek, yaitu siswa belum mampu mencantumkan kajian pustaka dalam laporan yang mendukung pelaksanaan penelitian, sumber kajian pustaka juga masih sangat terbatas dan belum mencantumkan daftar pustaka yang benar. Selain itu dalam presentasi, masih ditemukan siswa yang dominan dalam kelompoknya yang aktif menjawab pertanyaan kelompok lain. Pada siklus 2 nilai $>80$ berjumlah 32 siswa (88\%). Tindakan perbaikan pada siklus 2 melalui proyek secara bebas, maksudnya siswa bebas memilih persoalan sendiri yang akan diteliti, sehingga sebagian besar siswa aktif dalam kegiatan presentasi.

Project Base Learning dalam pembelajaran Kimia memiliki keuntungan-keuntungan yaitu: membantu siswa menjadi lebih otonomi, mengatur sendiri dan bertanggung jawab terhadap belajar mereka sendiri melalui proyek. Siswa termotivasi ketika mereka melakukan pembelajaran dengan riset sederhana. Siswa belajar untuk memanipulasi lingkungan mereka menjadi lebih aktif. Hal ini akan memberikan peningkatan pada hasil belajar.

Penilaian produk dilakukan terhadap proses pembuatan produk dan kualitas suatu produk. Pengembangan produk meliputi 3 tahap penilaian. (1) desain produk; (2) menyeleksi menggunakan bahan, alat dan teknik;(3) produk yang dihasilkan sesuai dengan kriteria yang diharapkan. Penilaian produk ini tidak bersifat tunggal pada obyek produk saja. Siklus 1 menunjukkan 25 siswa (69\%) yang sudah mampu menyeleksi penggunaan bahan dan selebihnya perlu penyempurnaan. Pada siklus 2 sudah ada peningkatan dari nilai fungsi dan estetikanya terdapat 34 siswa (94\%) menghasilkan sebuah produk berkualitas yang bermanfaat bagi siswa dan lingkungan.

\section{KESIMPULAN}

Berdasarkan Penelitian Tindakan Kelas tentang penerapanm Project Based Learning pada konsep Polimer dalam bentuk slime diperoleh kesimpulan sebagai berikut:

1. Project Based Learning pada konsep Polimer dalam bentuk slime dapat mengembangkan kemampuan Life Skill siswa Kelas XI IPA-4 MAN Tuban TP 
2016/2017. Kegiatan penemuan konsep yang dilakukan dengan pemecahan permasalahan menghasilkan produk melalui proyek dalam kehidupan sehari-hari, menjadikan siswa dapat menghubungkan materi pelajaran yang telah diperoleh . Hal ini dapat dilihat dari nilai kinerja siswa dalam menyelesaikan proyek untuk menghasilkan produk dan hasil angket minat siswa.

2. Project Based Learning pada konsep Polimer dalam bentuk slime dapat meningkatkan hasil belajar siswa Kelas XI IPA-4 MAN Tuban TP 2016/2017 dalam menjawab soal-soal penerapan konsep polimer. Nilai formatif menunjukkan 30 siswa (83\%) mendapat nilai $>80$, nilai laporan kegiatan praoyek 32 siswa $(88 \%)$ mendapatkan $>80$ dan nilai produk 34 siswa (94\%) menghasilkan produk yang berkualitas.

Adapun saran yang dapat diberikan saran sebagai berikut:

1. Perlu dilakukan tindaklanjut dari hasil penelitian ini dalam kegiatan belajar mengajar disekolah karena berdasarkan hasil penelitian ini siswa sangat dimungkinkan untuk mencapai kompetensinya.

2. Guru perlu melakukan inovasi dari hasil penelitian, agar pembelajaran dikelas dapat terus diupayakan untuk diatasi.

\section{DAFTAR RUJUKAN}

Arikunto, Suharsimi. 2013. Prosedur Penelitian Suatu Pendekatan Proyek Jakarta: Rineksa Cipta

Carrin Arthur. A. 2009. Project Based Learning. Columbus: Merril Publishing Company.

Djamarah. 2013. Strategi Belajar Mengajar. Jakarta: Rineksa Cipta.

De Porter. Bobby. 2009. Quantum Teaching. Bandung: Mizan Media Utama.

Eugine. Friedman. 2004. FundamentalProject. Journal International of Interactive Learning Reseach. Vol 13

Munandar. 2009. Proses Belajar Mengajar. Bandung:Remaja Rosdakarya.

Thontowi. 2016. Uji Coba Pembelajaran Mandiri. Semarang: UNNES.

Tim Broaf Based Education (BBE) Depdiknas. 2011. Pola Pelaksanaan Pendidikan Kecakapan Hidup. Surabaya: SIC bekerja sama dengan LPM UNESA 